Miami Nature Biotechnology Short Reports

TheScientificWorld (2001) 1(S3), 34SR

ISSN 1532-2246; DOI 10.1100/tsw.2001.157

\title{
THE BLOOM SYNDROME PROTEIN BLM IS SELECTIVELY CLEAVED DURING APOPTOTIC CELL DEATH
}

Oliver Bischof*, Sanjeev Galande $\ddagger$, Terumi Kohwi-Shigematsu‡, Judith Campisił, Anne Dejean*

Dept. Retrovirus, Unité Recombinaison et Expression Génétique, Institut Pasteur, France; $¥$ Life Sciences Division, Lawrence Berkeley National Laboratory, 1 Cyclotron Road, Berkeley CA 94720, USA

* obischof@pasteur.fr

INTRODUCTION. Bloom syndrome (BS) is an autosomal recessive disorder characterized by a high incidence of cancer and genomic instability. BLM, the protein defective in BS, is a RECQ-like helicase that is presumed to function in mammalian DNA replication, recombination or repair. Because of its importance in maintaining genomic stability, we asked whether BLM was among the proteins targeted for selective degradation during the execution phase of apoptosis as has been shown recently for PARP and ATM (1, 2), among others. We show here that BLM is rapidly cleaved in cells undergoing apoptosis.

RESULTS. BLM was cleaved to 47 and $110 \mathrm{kDa}$ major fragments, with kinetics similar to the apoptotic cleavage of poly-ADP ribose polymerase (only $\triangle B L M$ of $47 \mathrm{kDa}$ is shown in the Fig.). BLM cleavage was prevented by a caspase 3 inhibitor, and did not occur in caspase 3deficient cells. Moreover, recombinant BLM was cleaved to 47 and $110 \mathrm{kDa}$ fragments by caspase 3 , but not caspase 6 , in vitro. The caspase 3 recognition sequence 412TEVD415 was verified by mutating aspartate-415 to glycine, and showing that this mutation rendered BLM resistant to caspase 3 cleavage. Apoptotic cleavage did not abolish the BLM helicase activity, but abolished BLM nuclear foci and the association of BLM with condensed DNA and the insoluble matrix. The results suggest that BLM is an early selected target during the execution of apoptosis.

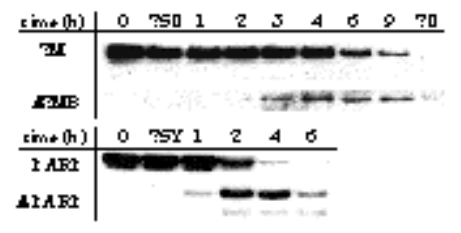

DISCUSSION. Caspases are important for both the initiation and execution phases of apoptosis (3-5). At present, there is a need to identify caspase substrates in order to understand how caspases execute apoptosis. In recent years, a number of caspase substrates have been identified (5). Here, we show that BLM is a substrate for the executioner caspase 3, in vitro 
and in vivo. Immunostaining and biochemical fractionation showed that cleaved BLM lost its characteristic punctate nuclear localization, detached from an insoluble substructure, and dissociated from condensed DNA. Cleavage and loss of localization very likely obliterates the in vivo function of BLM. The potential function of BLM in DNA repair suggests that its cleavage and redistribution may aid nuclear disassembly and prevent the complex in which it resides from participating in the repair of fragmented DNA molecules generated by caspaseactivated DNAse I.

ACKNOWLEDGEMENT. This work was supported by Marie-Curie Fellowship BMH4CT98-5129 to OB, grants from the National Institutes of Health GM59901 to TKS and AG11658 to JC, and a program project grant from the U. S. Department of Energy, under contract DE-AC03-76SF00098 to the University of California.

\section{REFERENCES.}

1. Lazebnik, Y.A., Kaufmann, S.H., Desnoyers, S., Poirier, G.G., and Earnshaw, W.C. (1994) Nature 371, 346-347

2. Smith, G.C., di Fagagna, F., Lakin, N.D., and Jackson, S.P. (1999) Mol. Cell. Biol. 19, 6076-6084

3. Cohen, G.M. (1997) Biochem. J. 326, 1-16

4. Budihardjo, I., Oliver, H., Lutter, M., Luo, X., and Wang, X. (1999) Annu. Rev. Cell Dev. Biol. 15, 269-290

5. $\quad$ Earnshaw, W.C., Martins, L.M., and Kaufman, S.H. (1999) Annu. Rev. Biochem. 68, 383424 

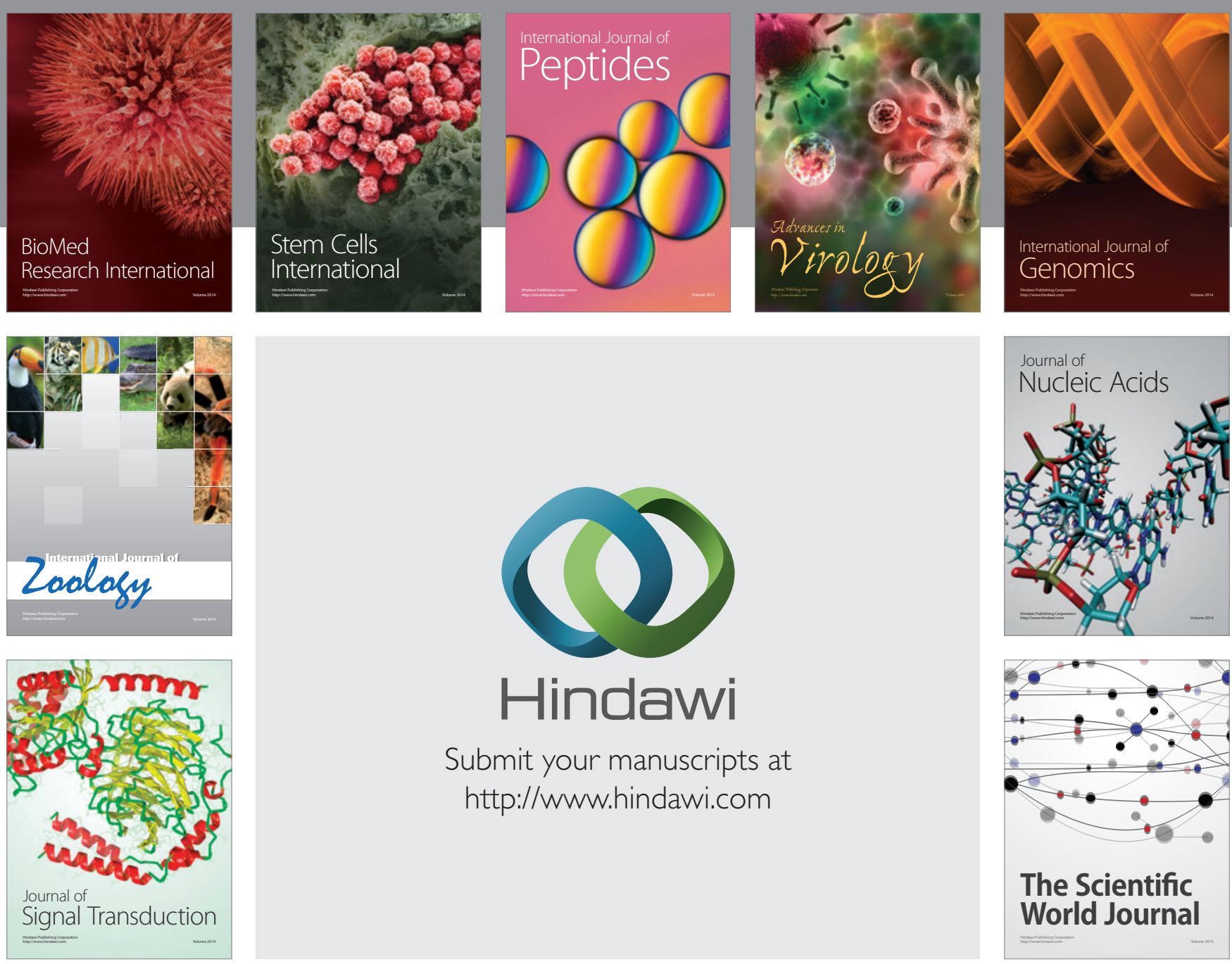

Submit your manuscripts at

http://www.hindawi.com
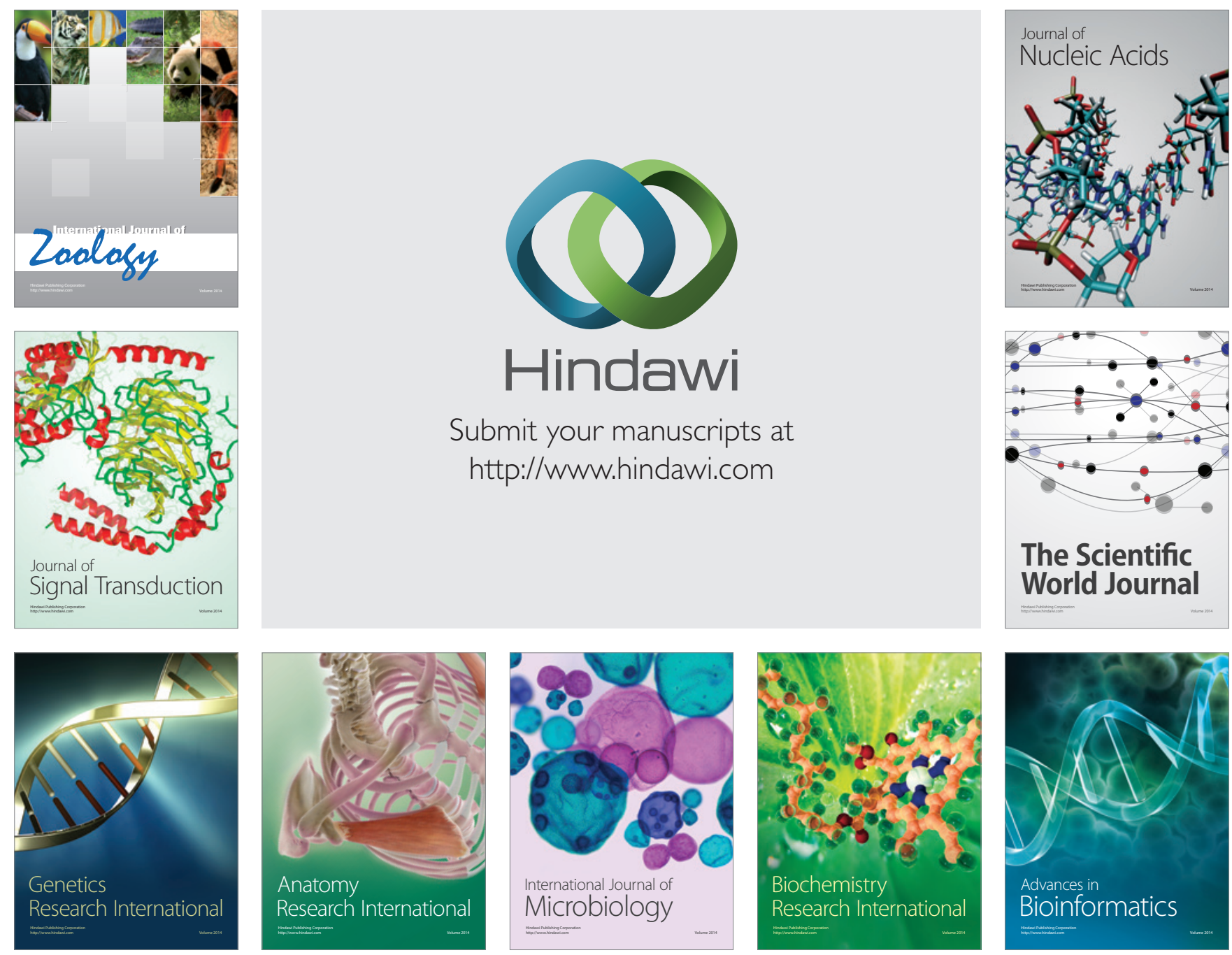

The Scientific World Journal
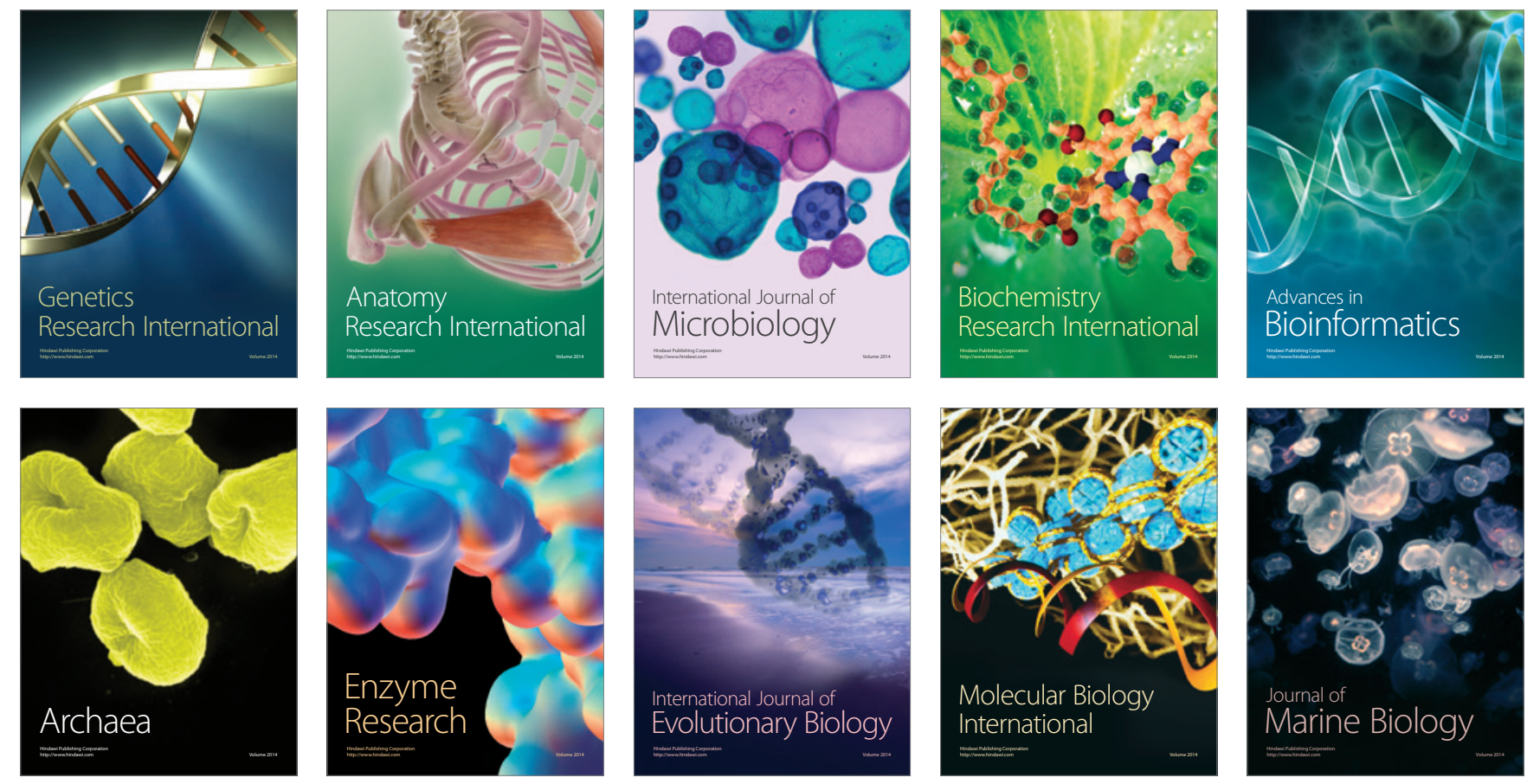